\title{
REFLECTIONS
}

\section{On This Day of Mothers and Sons}

Sara G. Sbields, MD, MS

Family Health Center of Worcester, Worcester, Mass

Conflicts of interest: none reported

\section{CORRESPONDING AUTHOR}

Sara G. Shields, MD, MS

26 Queen St

Worcester, MA 01610

Sara.ShieldsFHCW@umassmed.edu

\begin{abstract}
Telling a pregnant woman and her family about a fetal demise is one of the greatest challenges for maternity care clinicians. In this essay, the author reflects on such an encounter in her work as a community health center clinician, maternity care teacher, and mother herself.
\end{abstract}

Ann Fam Med 2005;3:367-368. DOI: 10.1370/afm.379.

$\mathrm{T}$ he morning begins in celebration, my son brightly leaping awake in joyful anticipation of his eighth birthday unfolding before him. This day will truly be his. Before work, I share the merriment of his breakfast birthday gifts and then kiss him good-bye more wistfully than usual. My happiness at his excitement is tinged both with memory of his newborn self so fleetingly long ago and with sadness at departing for work. This day should be fully his - and fully mine to be there as I was at the beginning. But he seems unaware and is too busy thinking about his latest Lego and his upcoming party to give me more than a quick airborne hug.

At work, I, too, become busy thinking about other things, enveloped in the tumult of my overbooked schedule at a community health center. After a couple of patients do not show, I have a breather to finish notes in a chart at the nurses' station. When our obstetric nurse-practitioner approaches me, I expect her usual quick curbside question about a newly pregnant woman's medication list or yesterday's telephone messages. But she is somber and succinct as she hands me her Doptone. "I'm seeing a woman at 30 weeks' with no fetal movement for a week and no fetal heart tones now." I put down my pen immediately to follow her. Somehow in her tone and my response, we both wordlessly know that if she cannot find the heartbeat, I probably cannot either.

I enter the examination room and introduce myself to the woman sitting on the examination table. She's Salvadoran, quiet with respect for doctors, neatly dressed, and carefully coiffed. Her prenatal history is unremarkable ${ }_{i}$ her 2-year old daughter is at home while her sister-in-law dropped her off for this visit. She knows this baby is a boy-she paid for a sonogram to know that.

I ask a few questions about her history and symptoms as I wash my hands; I query again about when she last felt movement and explain that I will also try to listen for the baby. In these first few moments of meeting each other, I cannot quite read her face. I wonder silently what kept her from calling sooner than this regularly scheduled appointment and what she thinks could be wrong.

I put my hands gently on her soft belly, feeling for her uterus and the baby's position before I reach for the Doptone. Under my hands, her fundus is soft, the baby still. I listen in the usual places, moving the Doptone around, searching for the swift swishing sound of life's pulse, but hearing only static. The nurse-practitioner knocks on the door to tell me that luckily for us our sonography technician is available immediately. I look this mother in the eye and make a swift decision to be completely honest right 
now: I say in my pretty good but not perfect Spanish, "Well, sometimes we can't hear the heartbeat because of the way the baby is lying, with his back to your back, so we need to get an ultrasound to check for sure; and sometimes, when you haven't felt him and we can't hear him, that may mean the baby's died."

Her face, expectant on mine, crumples as she gasps at these words. I so swiftly, desperately want to take them back. Why have I said this now, before the sonogram? Maybe I'm wrong? Why am I taking away any hope now with these blunt, harsh words? Maybe I should have used an interpreter? And yet part of me knows that somehow in her almost unreadable gaze she already knows, even as she still hopes.

In the sonography room, the technician moves the transducer around, searching, and we wait, looking at the machine, hoping. Our silence merely voices the certainty of what we are about to say. If there were a heartbeat, wouldn't we be instantly telling her, showing her, reassuring her with our relieved smiles? In our hesitation, she knows the final truth, reads it in our quiet unsmiling faces. She gasps and sobs anew as I turn to her and repeat now, with this photographic certainty, what I already said-_Your baby has died. I am so, so sorry." My voice trails off. I touch her hand and let her cry, her sobs shaking the grainy ultrasound view as the technician tries to finish her pictures. I don't think the technician wanted her to know quite yet, but I can't let her wait longer. "I am so sorry," I say again.

The long walk back to the examination room is eerie. I suggest a moment to collect ourselves as the walk takes us through two crowded waiting rooms. I know the spectacle we make-not the expected joy of pregnancy but rather a red-eyed pregnant woman with somber companions. Back in the examination room, with a box of tissues at hand, she meets my gaze with simple questions, the ones I'm waiting for- "Why? What now?" She wants to call her husband, her sisterin-law. I hold her hand, I tell her in broad terms some of her options. I tell her for now there are no answers, but some will come. I tell her this is not her fault. I tell her again how sorry I am. I spend most of the rest of my morning with her.

I teach residents how to do this telling, I've read about how to do it, I've watched videos, I've had advice from other faculty and heard their wisdom, I've even had to deliver such news a few other times in my career. Yet right now, in the agony of this woman's experience, on this day that began for me with celebrating my own mothering moments, I feel so very deeply the blunt, hard pain of this mother, this moment of knowing death. I am the one who has to move those shocking diagnostic words out of their sticking place in my throat to tell her news that I, as a mother, know is unfathomably agonizing. When I tell such news in the future, it will never be with the distance of protocols or practiced professional phrases, but always with my personal awareness of the boundless depth of maternal love and the inextricable potential for maternal suffering. Indeed, this day teaches me again how interwoven are my personal knowledge of human connections and my professional work with families.

Later this day I talk with this woman's primary care physician, a resident, herself on duty that evening. I tell her I'm on my way to my son's birthday party, and she exclaims, "Today is my son's birthday too!" So here we are: the grieving woman, her primary doctor, and the doctor this woman didn't know before today. We are all mothers who have felt baby sons kick within us. Today, two of us celebrate our sons' growth and life, always remembering those movements. The third one of us, whose unborn son no longer kicks within, will grieve always, remembering this day.

To read or post commentaries in response to this article, see it online at http://www.annfammed.org/cgi/content/full/3/4/367.

Key words: pregnancy; childbirth; puerperium

Submitted September 17, 2004; submitted, revised, February 22, 2005; accepted March 14, 2005.

Acknowledgments: The author is grateful for editing assistance from the members of the Teacherless Writing Group at the University of Massachusetts Department of Family Medicine and Community Health. 